ROCZNIKI NAUK PRAWNYCH

Volume XXVIII, number $4-2018$

Englis h v e r s i o n

DOI: http://dx.doi.org/10.18290/rnp.2018.28.4-9en

\title{
THE FORMATION OF THE CONCEPT OF A HERMIT, OR AN ANCHORITE, IN THE LIGHT OF THE LATIN CHURCH LAW CODIFICATION AFTER THE SECOND VATICAN COUNCIL
}

\section{INTRODUCTION}

In its description of the eremitic life in the Latin Church contained in 603, $\S 1$ of the 1983 Code of Canon Law, ${ }^{1}$ the legislator uses two terms in the phrase "vita eremitica seu anachoretica," which were rendered into Polish as "eremitic or anchoritic life." In order to analyse the Latin historical and legal origins of the phrase "hermit or anchorite," we will look at the semantics and phraseology of the Latin terms eremita and anachoreta. To this end, the article will employ the dogmatic-legal method. The core literature on anchoretism is rich, especially in French ${ }^{2}$ and English. ${ }^{3}$ Some results of research in

Rev. MARCin BIDER, PhD, is an assistant professor at the Department of Law, Faculty of Economic and Legal Sciences, of the Siedlce University of Natural Sciences and Humanities; address: Żytnia 17/19, 08-110 Siedlce, Poland; e-mail: biderus@op.pl; https://orcid.org/ 00000001-9446-1753.

${ }^{1}$ Codex Iuris Canonici auctoritate Ioannis Pauli PP. II promulgatus, January 25, 1983, AAS 75 (1983), pars II, 1-317; Polish translation in Kodeks Prawa Kanonicznego, approved by the Polish Episcopal Conference (Poznań: Pallottinum, 1984); for the English translation of this article the CLSA text of the Code has been used as posted on the Vatican website [henceforth quoted as $\mathrm{CIC} / 83$.

${ }^{2}$ An extensive list of references for this subject can be found in: P. PILSZAK, L'actualité de la vocation a la vie érémitique pour l'Eglise d'aujourd'hui (Ouagadougou: Grand Séminaire Saint Jean-Baptiste de Wayalghin, 2012), (manuscript made available by the Author); H. HEMmer, "Anachorètes," in Dictionnaire de Théologie Catholique, ed. A. Vacant et al. (Paris: Letouzey et Ané, 1909), vol. 1, coll. 1134-41; H. LECLERCQ, "Erémitisme," in Dictionnaire d'Archéologie Chrétienne et de Liturgie, ed. F. Cabrol and H. Leclercq (Paris: Letouzey et Ané, 1922), vol. 5/1, coll. 384-86; P. Doyere, "Ermites," in Dictionnaire de Droit Canonique, ed. R. Naz (Paris: Letouzey et Ané, 1953), vol. 5, coll. 412-29; C. LiAtine, "Érémitisme," in Dictionnaire de Spiritu- 
anchoretism have also been published in Polish. ${ }^{4}$ The first monks appeared in the East, and the monastic life became an integral part of the eastern "luminis," which was later conveyed to the Latin West. ${ }^{5}$

\section{TERMINOLOGY}

The Greek term anachōrēta, ${ }^{6}$ which was commonly used until the fifth century, ${ }^{7}$ denoted a monk living in "anachoresis" ( $\left.\alpha v \alpha \chi \omega \rho \eta \sigma \iota \varsigma\right),{ }^{8}$ which is

alité Ascétique et Mystique Doctrine et Histoire, ed. M. Viller, C. Baumgartner, and A. Rayez (Paris: Beauchesne, 1960), vol. 5, coll. 936-83.

${ }^{3}$ Since the publication of R.M. CLAY, The Hermits and Anchorites of England (London: Methuen \& Co, 1914), http://www.historyfish.net/anchorites/clay_anchorites.html [accessed April 8, 2018], not much new data in the literature on institutions of anchorites have been furshished, especially of those inhabiting medieval England. In recent years, however, the literature on the subject has been broadened to include much newer works, including A.K. WARREN, Anchorites and their Patrons in Medieval England (Berkeley-Los Angeles-London: University of California Press, 1985); E.A. JonES, "Rites of Enclosure. The English «Ordines» for the Enclosing of Anchorites," Traditio 67 (2012): 145-234; M. Hughes-EdWARDS, "Solitude and Sociability. The World of the Medieval Anchorite," accessed April 8, 2018, http://www.building conservation.com/articles/anchorites/anchorites.htm.

${ }^{4}$ H. ŚMIAROwSKI, Pustelniczy kan. 603: uregulowania kanoniczne diecezjalnego życia pustelniczego w Kościele rzymskokatolickim (Ełk: Fundacja Szlakiem JP2, 2016); A. SKORUPA, "Wymiar strukturalny życia pustelniczego," accessed April 8, 2018, http://www.ifzk.episkopat.pl/ dokumenty/sympozjum2016konf-3.pdf.

${ }^{5}$ For more on the historical sources of anchoretism in the Latin Church, see, for example M.G. Miles, Canon 603. Diocesan Hermits in the Light of Eremitical Tradition (Rome: Pontificia Universitas Gregoriana, 2003), 11-114.

${ }^{6}$ In ancient Egypt, anchorites were initially known as peasants who, having abandoned their own farms, went to the desert to evade taxes. Over time, a man, less frequently a woman, would go to secluded places in a conviction that only abandonment of the world was the proper fulfilment of the ideal of Christian life, which was the only way to salvation, see: H. ĆWIKLIŃSKI, "Anachoreci," in Encyklopedia Katolicka, ed. F. Gryglewicz, R. Łukaszyk, and Z. Sułowski (Lublin: Towarzystwo Naukowe KUL, 1989), vol. 1, col. 475. J. GRIBOmOnT, "Anacoreta," in Nuovo dizionario patristico e di antichità cristiane, vol. 1, A-E, ed. A. Di Berardino (Genova-Milan: Marietti, 1820, 2008), col. 257.

${ }^{7}$ M. Daniluk and J. Duchniewski, "Eremici. I. Podstawy ideowe," in Encyklopedia Katolicka, ed. F. Gryglewicz, R. Łukaszyk, and Z. Sułowski (Lublin: Towarzystwo Naukowe KUL, 1989), vol. 1, coll. 1069-70.

${ }^{8}$ In ancient times, the strip of Egyptian sand desert located along the waters of the Nile was reclaimed and developed. Here were numerous temples, necropoli and quarries; occasionally, human settlements were found in this belt. It was also a place to take refuge for those who embarked on anachoresis, interpreted as withdrawal, departure from the benevolent land to the desert (G.W.H.

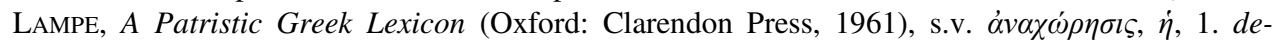
parture, p. 129). The motivation to go to the desert was diverse. Egyptian peasants decided to take 
the voluntary abandonment of the world by choosing to live in complete isolation. The term anachoresis, meaning an original departure, already known in classical Greek, occurs in the Septuagint (see Numbers 16:24, 2 Maccabees 5:27, 2 Maccabees 10:13) ${ }^{9}$ and the Greek New Testament (see Matthew 12:15, Matthew 14:13, and Matthew 15:21), ${ }^{10}$ acquiring a metaphorical meaning. ${ }^{11}$

The term $\dot{\alpha} v \alpha \chi \omega \rho \eta \tau \dot{\eta} \varsigma$, borrowed by Latin ecclesiastical writers, ${ }^{12}$ became a permanent feature of the "monasticon" thanks to Benedict of Nursia $(\dagger 547){ }^{13}$

this step during the harvest season to force powerful landowners to improve the living conditions of their families. The desert was also refuge for offenders persecuted by the authorities, insolvent debtors, and people who might be called "restless spirits." The escapees often sought refuge in caves or burial chambers. The Greek term anachoresis was used to refer to this type of escape to the desert, which from the fourth century became an exclusively Christian term (E. WIPSZYCKA, Introduction for Athanasıus, Żywot świętego Antoniego. Św. Antoni Pustelnik. Pisma (Warszawa: Instytut Wydawniczy PAX, 1987), 14; H. DYBSKI, "Początki anachretyzmu w Egipcie w świetle nauczania Ojców Kościoła IV i V wieku,” Studia Teologiczne 27 (2009), 205-9. Anchorites referred to the commandment given by Jesus Christ in Matthew 19:21 ("If you want to be perfect, go, sell everything you have, and give it to the poor, and you will have treasure in heaven. Then come and follow me").

${ }^{9}$ Septuaginta. Id est Vetus Testamentum graece iuxta LXX interpretes edidit Alfred Rahlfs. Editio altera quam recognovit et emendavit Robert Hanhart. Complete Text without Apparatus (Stuttgart: Deutsche Bibelgesellschaft, 2006), 184, 702, 709.

${ }^{10}$ Grecko-polski Nowy Testament. Wydanie interlinearne $z$ kodami gramatycznymi, $7^{\text {th }}$ ed., ed. R. Popowski and M. Wojciechowski (Warsaw: Oficyna Wydawnicza Vocatio, 1994), 52, 67, 73.

${ }^{11}$ Jesus retired symbolically towards Tyre and Sidon, i.e. pagan communities. His anachoresis from among the Jews is mentioned three times by Matthew. In this way, the Evangelist emphasizes the growing distance between the Teacher of Nazareth and the officials of Israel. The first anachoresis was performed by Jesus after his confrontation with the Pharisees, who definitely rejected him as the Messiah; what is more, they resolved to kill him when he first suggested to them that he was greater than the Temple, that he was the Lord of the Sabbath (see Matthew 12:1-13). In reply, Jesus Christ "withdrew from there" (Matthew 12:15). Then the martyrdom of John the Baptist led Jesus Christ to leave Galilee "for a desert place." In the death of John the Baptist, Jesus Christ saw the anticipation of his own passion. The departure of Jesus Christ is mentioned for the third time in the passage at hand as a result of a discussion between the Pharisees and Scribes who accused his disciples of flaunting the traditions of the Elders. In the vicinity of Magadan, there was a definitive confrontation of Jesus and the Jews who, while demanding a sign from heaven that would legitimize the Messiah's teachings, disregarded the miracle of bread multiplication and the numerous healings (see Matthew 16:1-4). This time Jesus is definitely "leaving them" (see Matthew 16:4(b) to their own obduracy. Likewise, he ordered his disciples to do the same: "Leave them alone!" (Matthew 15:14) (J. MACIĄG, "XX niedziela zwykła "A" [Mt 15, 21-2]_Jezus i udręczony świat pogański," accessed April 8, 2018, http://./index.php/slowo-na-niedziele/lectio-divina/3446-uhyjiyuyu.

${ }^{12}$ A. Sidonius, Carmina, 16, 97, in A. Sidonius Epistvlae and Carmina, 2nd ed. (Munich: Monumenta Germaniae Historica, 1985), 241.

${ }^{13}$ Benedict of Nursia $(\dagger 547)$ classified anchorites in his Rule (Chapter 1 entitled On the Kinds of Monks) to the second kind of monks, who "no longer in the first fervour of their refor- 
Both terms, anchorite ( $\dot{\alpha} v \alpha \chi \omega \rho \eta \tau \dot{\eta} \varsigma)$ and hesychast $(\dot{\eta} \sigma v \chi \alpha \sigma \tau \dot{\eta} \varsigma),{ }^{14}$ became equivalents of the Latin eremita, ${ }^{15}$ which in turn comes from the Greek term

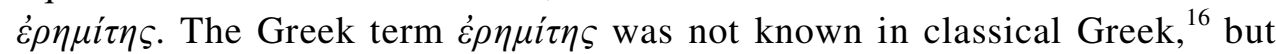
persisted in Christian literature, denoting a desert inhabitant ( $\tilde{\varepsilon} \rho \eta \mu \varsigma) .{ }^{17}$ Then the term eremita became a permanent feature of Latin, used, for example, by Sulpicius Severus $(\dagger \text { ca. } 420)^{18}$ and John Cassian $(\dagger$ after 432$) ;{ }^{19}$ the latter

mation, but after long probation in a monastery, having learned by the help of many brethren how to fight against the devil, go out well armed from the ranks of the community to the solitary combat of the desert. They are able now, with no help save from God, to fight single-handed against the vices of the flesh" (the Polish translation in Reguła, in Reguła Mistrza. Reguła św. Benedykta (Tyniec-Kraków: Wydawnictwo Benedyktynów, 2006), 392-93.

${ }^{14} \mathrm{~A}$ hesychast is a monk living in hesychasm, a state of mind and body necessary to achieve contemplation. In the Byzantine tradition, hesychasm is also considered a form of monastic life, consisting in keeping silent and having one's mind constantly immersed in contemplative prayer. It is characterized by freedom from worries, praying, heart-felt activities, keeping silent, fasting, humility, memory of death, contrition, non-irastiscibility, chastity, insomnia, and ecstasy. A hesychast achieves liberation from passions, acquiring the ability to distinguish between spirits, and theological infallibility (E. OSEK, "Apendyks 2. Leksykon terminów ascetycznych św. Jana Klimaka," in ST. Climacus, Drabina raju, ed. E. Osek (Kęty: Wydawnictwo Marek Derewiecki, 2011), 367.

${ }^{15}$ J. Gribomont, "Eremita. 1. Filologia," in Dizionario degli Istituti di Perfezione, ed. G. Pelliccia and G. Rocca (Rome: Edizioni Paoline, 1976), col. 1153. In the literature on the subject, the term eremita has been used alongside eremicula (L. FERRARIs, Prompta Bibliotheca Canonica, Juridica, Moralis, Theologica, nec non Ascetica, Polemica, Rubricistica, Historica, vol. 3 (Paris: J.P. Migne, 1852), s.v. "Eremita."

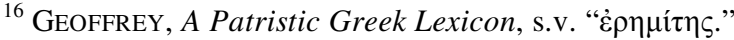

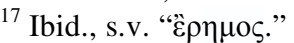

${ }^{18}$ Duo beati Antonii monasteria adii, quae hodie que ab eius discipulis incoluntur. Ad eum etiam locum in quo beatissimus Paulus primus eremita est diversatus, accessi” (SUlPICIUS Severus, Dialogus Primus 17, 1, in Libri qui supersunt. Corpus Scriptorum Ecclesiasticorum Latinorum, ed. C. Halm (Vindobonae: apud C. Geroldi Filium Bibliopolam Academiae, 1866), 1:169; Polish translation by P.J. Nowak, retranslated here as: "I made my way to two monasteries of St Antony, which are still inhabited by his disciples. I also arrived at this place where the blessed Paul sojourned-the fist hermit." See S. SEverus, "Dialogi o życiu św. Marcina," in $P i$ sma o św. Marcinie z Tours. Żywot, listy, dialogi, ed. M. Starowieyski (Tyniec-Kraków: Wydawnictwo Benedyktynów, 1995), 130.

${ }^{19}$ John Cassian ( $\dagger$ ca. 435$)$ wrote of anchorites that "quidam enim summam intentionis suae erga heremi secreta et cordis constituunt puritatem, ut in praeteritis Heliam et Helisaeum nostris que temporibus beatum Antonium alios que eiusdem propositi sectatores familiarissime deo per silentium solitudinis cohaesisse cognoscimus" (John CASsian, Opera, Pars II, Co[n]lationes XXIIII, conference 14, chap. 4 [Corpus Scriptorum Ecclesiasticorum Latinorum, ed. M. Petschenig (Vindobonae: apud C. Geroldi Filivm Bibliopolam Academiae, 1886), 400; Polish translation by Arkadiusz Nocon; English translation retrieved from the web project documentacatholica omnia.eu, http://www.documentacatholicaomnia.eu/03d/0360-0435,_Cassianus,_The_Conferences_Of_John

_Cassian,_EN.pdf: "For some make it their whole purpose to aim at the secrecy of an anchorite and purity of heart, as we know that in the past Elijah and Elisha, and in our own day the blessed Antony and others who followed with the same object, were joined most closely to God by the 
contrasted hermitism ${ }^{20}$ with cenobitism. ${ }^{21}$ The term eremita appears also in the writings of Saint Jerome $(\dagger 419) .{ }^{22}$ In the Middle Ages, eremita made its way to Romance languages, becoming a synonym for a hermit or a monk. In Medieval Latin, which was used in the lands of the Polish Crown, the following were used interchangeably: eremita, heremita or hermitha-as synonyms for a hermit ("anachoreta in eremo habitans") or a member of an eremitic order ("monachus, qui vitam solitariam in eremo agit"), ${ }^{23}$ or later in the sixteenth century a member of the order dedicated to St Paul the First Hermit

silence and solitude" (John CASSIAN, Rozmowy z ojcami, vol. 2, Rozmowy XI-XVII, ed. S. Hiżycki (Tyniec: Wydawnictwo Benedyktynów, 2015), 217.

${ }^{20}$ The [Polish] term "erem" [Eng. hermitage] has the same origin, first used by Rufinus of Aquileia († ca. 411/12) to designate a monk's residence. In the same sense, as it seems, it was used in the first half of the fifth century in a description of holy places in Palestine (Itinerarium Egeriae 16, 5 in Itineraria et alia geographica. Itineraria Hierosolymitana. Itineraria Romana. Geographica. Corpus Christianorum Series Latina, ed. P. Geyer et al. (Brepols: Turnhout, 1965), 57-58). Therefore, in the monastic literature of the Latin West, hermits were monks who sought absolute solitude, who would not get involved in community life, just like later, in the Middle Ages and modernity (e.g. Hermits of Saint-Sever and Hermits of Porta Angelica in Rome) (M. DANILUK, Encyklopedia instytutów życia konsekrowanego i stowarzyszeń życia apostolskieg (Lublin: Redakcja Wydawnictw KUL, 2000), s.v. "Anachoreci” and "Eremici”).

${ }^{21}$ Cenobites are individuals who keep, with other faithful living outside the monastery, the full unity of heart and spirit, following the example of the original Jerusalem community; they are internally integral people who are not torn between the world and God, achieving internal unity through unification with Him (M. DANILUK, "Mnich," in Encyklopedia Katolicka, ed. E. Ziemann (Lublin: Towarzystwo Naukowe KUL, 2008), vol. 12, coll. 1447; see M.G. Bianco, "Cenobio, cenobita," in Nuovo dizionario patristico, vol. 1, coll. 984-85).

22 "There are in Egypt three kinds of monks. First, there are the cenobites, called in their Gentile language Sauses, or, as we should say, men living in a community. Secondly, there are the anchorites, who live in the desert, each man by himself, and are so called because they have withdrawn from human society. Thirdly, there is the class called Remoboth, a very inferior and little regarded type, peculiar to my own province, or, at least, originating there [Jerome probably meant Pannonia]. These live together in twos and threes, but seldom in larger numbers, and are bound by no rule; but do exactly as they choose. A portion of their earnings they contribute to a common fund, out of which food is provided for all. In most cases they reside in cities and strongholds; and, as though it were their workmanship which is holy, and not their life, all that they sell is extremely dear. They often quarrel because they are unwilling, while supplying their own food, to be subordinate to others. It is true that they compete with each other in fasting; they make what should be a private concern an occasion for a triumph. In everything they study effect: their sleeves are loose, their boots bulge, their garb is of the coarsest. They are always sighing, or visiting virgins, or sneering at the clergy; yet when a holiday comes, they make themselves sick - they eat so much" (SAINT Jerome, Letter 22:34; Polish translation in Listy. Tom 1 (1-50). Tekst łaciński i polski, ed. H. Pietras (Kraków: Wydawnictwo WAM, 2010), 106*; English translation retrieved from http://www.newadvent.org/fathers/3001022.htm.

${ }^{23}$ J. MRUKównA, "Eremita s. heremita s. hermitha," in Stownik taciny średniowiecznej w Polsce, vol. 3/8, Entafilon-Exactionalis, ed. M. Plezia (Wrocław-Warszawa-Kraków-Gdańsk: Polska Akademia Nauk, 1973), col. 1168. 
("Ordo Fratrum s. Pauli Primi Eremitae"). ${ }^{24}$ According to Gaetano Moroni, a hermit is a pious man who stays in an isolated place in order to devote himself completely to God, with particular attention to oral prayer and contemplation of God's things. An anchorite should be distinguished from a hermit, who, according to Moroni, while being distanced from contact with the outside world, feeds on the collected plants, following in this way the example of St John the Baptist. The word "ascetic" became synonymous with the term "hermit." 25

\section{CODEX IURIS CANONICI}

Over time, when religious institutes became almost exclusively the only form of life based on evangelical counsels, eremitism, as its individual form in the eighteenth century, fell into oblivion. ${ }^{26}$ The 1917 Code of Canon $\mathrm{Law}^{27}$ did not regulate the legal status of hermits because it seemed that the institution of the anchorite had become a thing of the past. Since in accordance with canon $487 \mathrm{CIC} / 17$ the religious state is defined as "stabilis in communi vivendi" ${ }^{28}$ the anchorite's life as such was excluded from the category of religious life forms. Matthaeus Conte a Coronata, among others, considered such elements as "stabilis modus vivendi" and "in communi" as constitutive elements of the religious state.$^{29}$ Franciszek Bacczkowicz also believed that the eremitic life was not part of the religious state, even if hermits took vows to follow it. ${ }^{30}$ Heribertus Jone believed that "ad statum

\footnotetext{
${ }^{24}$ M. BORECKI, "Eremita," in Stownik polszczyzny XVI wieku, ed. M.R. Mayenowa et al., vol. 6, Dra-Eżby (Wrocław-Warszawa-Kraków-Gdańsk: Zakład Narodowy imienia Ossolińskich, Wydawnictwo Polskiej Akademii Nauk, 1972), 559.

${ }^{25}$ G. Moroni, Dizionario di erudizione storico-ecclesiastica da S. Pietro sino ai nostri giorni (Venice: Tipografia Emiliana, 1843), 22: 30.

${ }^{26}$ See F. Bogdan, Prawo zakonów, instytutów świeckich i stowarzyszeń życia apostolskiego (Poznań: Pallottinum, 1988), 29.

${ }^{27}$ Codex Iuris Canonici Pii X Pontificis Maximi iussu digestus Benedicti Papae XV auctoritate promulgatus praefatione emi Petrii Gaspari et indice analytico-alphabetico auctus (Rome: Typis Polyglottis Vaticanis, 1930) [henceforth quoted as CIC/17].

28 "Status religiosus seu stabilis in communi vivendi modus, quo fideles, praeter communia praecepta, evangelica quoque consilia servanda per vota obedientiae, castitatis et paupertatis suscipiunt, ab omnibus in honore habendus est" (c. 487 CIC/17).

${ }^{29}$ M. CONTE A CORONATA, Institutiones iuris canonici ad usum utriusque cleri et scholarum, vol. 1, Normae generales. De clericis. De religiosis. De laicis (Taurini: Marietti, 1939), pp. 604-5, no. 500.

${ }^{30}$ F. Baczkowicz, J. Baron, and W. Stawinoga, Prawo kanoniczne. Podręcznik dla duchowieństwa, $3^{\text {rd }}$ ed. (Opole: Wydawnictwo Diecezjalne św. Krzyża, 1957), 1: 610, no. 614.
} 
religiosum non pertinet qui vitam eremiticam seu solitariam ducit," although its observance, as he argued, was not prohibited in the Church. ${ }^{31}$ Hence, Dominique Bouix, among others, referring to such authors as Francis Suarez $(\dagger 1617),{ }^{32}$ believed that observance of the communal life did not lay at the core of the religious state, even though the legislator forbade it in the form of non approbatam, which, according to him, should also include the eremitic life. The ban on eremitic life according to Bouix stemmed from the Church law. ${ }^{33}$ Such a position of canonists resulted from the long evolution of the concept of religious state. ${ }^{34}$

Hermits, on account of the obligation to lead a religious life "stabilis modus vivendi" and "in communi" (c. $487 \mathrm{CIC} / 17$ ), even if they took their vows, they were deprived of the status of members of religious institutes. Individual and independent hermits were not granted any legal status. At the same time, the legislator did not ban eremitic life. The communities of hermits lived according to the norms of diocesan law, obliging their members to take simple vows. However, as the World War II ended, in the time of intensified theological deliberations connected with the Second Vatican Council, the anchoretic lifestyle started to reappear in Europe. The dicasteries of the Holy See, faced with the ongoing phenomena, devoted much attention to anchoretism, resolving different cases on an individual basis. In practice, if any member of religious institutes wanted to take up eremitic life, he had to ask for exclaustration or an indult of secularisation (see c. 637-645 CIC/17), passing under the authority of the ordinary of the place. Sometimes an indult of departure was published in a special form ad nutum Sanctae Sedis, which consisted in that the professed who were granted this type of indult for an indefinite period of time remained outside the religious community until the Holy See decided otherwise. Individual cases were full of paradoxes because the professed who wanted to take up a life of stricter solitude than anchorites were obliged - at least temporarily - to leave the religious state, which they had once chosen of their free will and still wanted to live the evangelical counsels. Critics of the legal system in force at that time raised the objection that nobody demanded that the professed religious who were raised to the

\footnotetext{
${ }^{31}$ H. Jone, Commentarium in Codicem iuris canonici (Padeborn: Schöningh, 1950), 1:385.

${ }^{32}$ SuÁREZ, Francis, Operis de religione pars secunda: quae est De statu religionis ac tomus tertius in ordine complectens tractatum septimum [...]: in decem libros distributum, Book 2, chap. 4, no. 1 (Lugduni: sumptibus Iacobi Cardon \& Petri Cauellat, 1624), 91-92.

${ }^{33}$ D. BouIX, Tractatus de iure regularium: ubi et de religiosis familiis, quae vota solemnia, vel etiam simplicia perpetua non habent (Paris: apud Jacobum Lecoffre et Socios, 1857), 1: 54-56.

${ }^{34}$ See X. 3, 35, 2 (Friedberg II, coll. 596-97); see X. 3, 36, 9 (Friedberg II, col. 607).
} 
dignity of bishops leave the religious community. It was also argued that the professed members who had been granted permission to work outside the religious community were not obliged to give up all ties they had with the community. ${ }^{35}$

In the theological literature, the hermit's life also became the subject of numerous studies around 1952. It was then that the first publications appeared in the French magazine "La Vie Spirituelle" ${ }^{36}$ showing renewed interest in this kind of vocation in the Catholic Church. ${ }^{37}$ Vatican II addressed issues related to hermitic life in the context of the religious life. ${ }^{38}$

\section{REDACTION OF CANON 603 OF THE CODE OF CANON LAW}

Preliminary work on the wording of the future canon $603 \mathrm{CIC} / 83$ commenced as early as in 1966 and continued until $1977 .{ }^{39}$ Already during the 1966 session, the Commission decided that terms such as "hermit" and "anchorite" would be treated as synonyms in further redaction work. ${ }^{40}$ In the 1966 schema, the canon in question, redacted as canon 31, was given the

${ }^{35}$ WINANDy, "Eremita. In Occidente (statuto canonico)," in Dizionario degli Istituti di Perfezione, vol. 3, coll. 1154-55.

${ }^{36}$ ReCLUS TheOPHILE, "Plaidoyer pour l'érémitisme," La vie spirituelle 377 (1952), 230-42; P. DOYERE, "Complexité de l'érémitisme," La vie spirituelle 377 (1952), 243-55; IDEM, "L'érémitisme dans la vie spirituelle et dans la vie religieuse," La vie spirituelle 377 (1952), 278-88; A.M. HENRY, "L'érémitisme dans l'histoire," La vie spirituelle 377 (1952), 306-8.

${ }^{37}$ B. SzEwCZUL, Review of "I nuovi eremiti. La «fuga mundi» nell'Italia di oggi, Isacco Turina, Milano: Edizioni Medusa 2007, ss. 239," Prawo Kanoniczne 53, nos. 3-4 (2010): 347.

${ }^{38}$ VATICAN II, Dogmatic constitution on the Church Lumen gentium, November 21, 1964, AAS 57 (1965), 49-51; English translation available on the Vatican website; Polish translation in Sobór Watykański II: konstytucje, dekrety, deklaracje: tekst polski, $3^{\text {rd }}$ ed. photo offset, ed. J. Groblicki and E. Florkowski (Poznań: Pallottinum, 2000), pp. 148-50, no. 43-44; IDEM, Decree on the adaptation and reneval of religious life Perfectae caritatis, October 28, 1965, AAS 58 (1966), 702-3; Polish translation in Sobór Watykański II: Konstytucje, 264-65, no 1.

${ }^{39}$ A. GutiÉRREZ, "Schema Canonum. De institutis vitae consecratae per professionem consiliorum evangelicorum," Commentarium pro Religiosis et Missionaris 58 (1977), 3-34; IDEM, "Schema Novi Iuris pro Institutis perfectionis christianae," Commentarium pro Religiosis et Missionaris 58 (1977), 193-209; P. HEMPEREK and W. GÓRALSKI, Komentarz do Kodeksu Prawa Kanonicznego z 1983 r.,vol.1/1, Historia źródet i nauki prawa kanonicznego (Lublin: Redakcja Wydawnictw KUL, 1995), 150-54; A. SONDERMANn, Praedicatio silentiosa et ecclesia minor. Eremitisches Leben nach dem geltenden Recht der katholischen Kirche (Essen: Ludgerus Verlag, 2014), 78-88.

${ }^{40}$ Pontifical Commission for the Revision of the Code of Canon Law, Acta Commissionis. Opera Consultorum in parandis Canonum Schematibus. De Institutis Perfectionis, Communicationes 6, no. 1, (1974): 78. 
following wording: "monachus qui a mundo secendens vitam anachoreticam ducit ut in solitudine, quiete et silentio soli Deo vacare possit, alacri poenitentia atque assidua lectione et prece perfectam caritatem quaerens, non omissa sollicitudine pro tota Ecclesia, in iure nomine eremitae gaudet." Then, its wording, presented at the meeting of November 24, 1966 as canon 31, was as follows: "Nomine anachoretae seu eremitae venit monachus qui mundo omnino segregatus, vitam solitariam in quiete et silentio, assiuda prece, lectione at alacri poenitentia laudis sacrificium offert et arcana foecunditate apostolica_Ecclesiam dilatat." 42 However, in the final redaction, canon 31 took the form: "Nomine eremitae seu anachoretae venit religiosus qui vitam complete solitariam in quiete et silentio, assiduaque prece, lectione, labore at alacri poenitentia in laudis sacrificium offert et arcana foecunditate apostolica Ecclesiam ditat. ${ }^{, 43}$ The discussions of the November 1971 session-due to requests from various parts of the world-led to the introduction of Title V, "De vita eremitica"-also for editorial reasons - instead of Section V entitled "De institutis exemptis" to emphasize the significance of eremitic life. ${ }^{44}$ However, at the 1972 session, this title was deleted, proposing to retain canon $31,{ }^{45}$ which in the schema "De Institutis Perfectionis" of 1977 , already as canon 92 , was given the following wording: “ $\$ 1$. Praeter haec vitae consecratae Instituta Ecclesia agnoscit vitam eremiticam seu anachoreticam, qua christifideles arctiore a mundo secessu, solitudinis silentio, assidua prece et paenitentia, suam in laudem Dei mundi salutem vitam consecrant. §2. Eremita uti religiosus iure recognoscitur si tria

41 "The monk, who, while separating himself from the world, leads an anchoretic life, so that he may, in solitude, peace and quiet, give himself only to God, through zealous penance (solitude) and constant reading and prayer, seeking perfect love, not omitting to show the concern for the whole Church, legitimately enjoys the name of a hermit" (retranslated from the Polish version found in ŚmiarowsKi, Pustelniczy kan. 603, 24-25).

${ }^{42}$ Pontifical Commission for the Revision of the Code of Canon Law, Ex Actis Pontificiae Commissions Codici Iuris Canonici Recognoscendo. III: Coetus studiorum «De institutis Perfectionis» (Sessio I $\mathrm{a}^{\mathrm{a}}$ ), Communicationes 16, no. 2 (1984): 224. "The name of an anchorite or hermit is given to a monk who, completely separated from the world, offers his solitary life in peace and quiet, among constant prayer, reading and fervent penance, and who broadens the Church by means of mysterious apostolic fecundity" (retranslated from the Polish version found in ŚMIAROWSKI, Pustelniczy kan. 603, 25).

${ }^{43}$ Ibid., 239. "The name of a hermit or anchorite is given to a religious if he offers his utterly solitary life in peace and quiet, among constant prayer, reading, work and fervent penance, and who enriches the Church by means of mysterious apostolic fecundity" (retranslated from the Polish version found in ŚMIAROWSKI, Pustelniczy kan. 603, 25).

${ }^{44}$ Pontifical Commission for the Revision of the Code of Canon Law, Acta Commissionis. De Institutis Perfectionis, Communicationes 5, no. 1, (1973): 65.

${ }^{45}$ Ibid., 66. 
evangelica consilia, voto firmata, profiteatur et propriam vitaeem actionem sub ductu Ordinarii loci aut competentis moderatoris habeat at servet."

The schema De Institutis Perfectionis, including canon 92, §§1-2 that we are dealing with, on February 2, 1977 were submitted for consultation to the dicasteries of the Roman Curia, episcopal conferences, and unions of superiors general. ${ }^{47}$ The tenor of the edited canon $92, \S \S 1-2$ was discussed ${ }^{48}$ at a meeting on May 29, 1979. As a result of the 1979 session, the draft canonical norm was given the following wording as canon 38: " $\$ 1$. Praeter vitae consecratae Instituta, Ecclesia agnoscit vitam eremiticam seu anachoreticam, qua christifideles arctiore a mundo secessu, solitudinis silentio, assidua prece et paenitentia, suam in laudem Dei et mundi salutem vitam devovent. $\S 2$. Eremita uti in vita consecrata Deo deditus in iure recognoscitur si tria evangelica Consilia, voto vel alio sacro ligamine firmata, publice profiteatur in manu Episcopi dioecesani et propriam vivendi rationem sub ductu eiusdem servet." ${ }^{49}$ The Commission presented the 1979 schema to the Roman Pontiff on June 20, 1980 and then, on May 29, 1979 re-edited it in line with some of the proposed amendments. ${ }^{50}$ The canonical norm, now as canon 530,

\footnotetext{
${ }^{46}$ Pontifical Commission for the Revision of the Code of CANON Law, Schema canonum de Institutis vitae consecratae per professionem consiliorum evangelicorum (reservatum) (Vatican City: Typis Polyglottis Vaticanis, 1977), p. 28, c. 92: "§1. In addition to institutes of consecrated life, the Church recognizes the eremitic or anchoritic life by which the Christian faithful devote their life to the praise of God and the salvation of the world through a stricter withdrawal from the world, the silence of solitude, and assiduous prayer and penance. §2. A hermit is recognized by law as one dedicated to God in consecrated life if he or she publicly professes in the hands of the diocesan bishop the three evangelical counsels, confirmed by vow or other sacred bond, and observes a proper program of living under his direction." ŚMIAROWSKI, Pustelniczy kan. 603, 26).

${ }^{47}$ Pontifical Commission for the Revision of the Code of CANOn Law, Acta Commissionis. Schema «De Institutis vitae consecratae» transmittitur, Communicationes 9, no. 1 (1977): 52.

${ }^{48}$ IDEM, Acta Commissionis. Opera Consultorum in recognoscendis schematibus canonum. II: Coetus studiorum de Institutis vitae consecratae per professionem consiliorum evangelicorum, Communicationes 11, no. 2 (1979): 328-31.

${ }^{49}$ Ibid., 328. " $\$ 1$. In addition to (those) institutes of consecrated life, the Church recognizes the eremitic or anchoritic life (recognizes hermits, that is, anchorites) by which the Christian faithful pledge to surrender (devote, offer) their life to the praise of God and the salvation of the world through a stricter withdrawal from the world, the silence of solitude, and fervent prayer and penance. \$2. A hermit is recognized by the law of the Church as one dedicated to God in consecrated life if he publicly professes in the hands of the diocesan bishop (or the proper superior) the three evangelical counsels, confirmed by vow or other sacred bond, and observes a proper course of life under his direction (one or the other)" (retranslated from the Polish version found in Śmiarowski, Pustelniczy kan. 603, 27).

${ }^{50}$ Pontifical Commission for the Revision of the Code of Canon Law, Relatio, Complectens Synthesim animadversionum ab Em.mis atque Exc.mis Patribus Commissions ad Novissimum Schema Codicis Iuris Canonici Exhibitarum, cum responsionibus a secretaria et
} 
$\S \S 1-2$ was given the following wording: "§1. Praeter vitae consecratae Instituta, Ecclesia agnoscit vitam eremiticam seu anachoreticam, qua christifideles, arctiore a mundo secessu, solitudinis silentio, assidua prece et paenitentia, suam in laudem Dei et mundi salutem vitam devovent; §2. Eremita uti in vita consecrata Deo deditus in iure recognoscitur si tria evangelica consilia, voto vel alio sacro ligamine firmata, publice profiteatur in manu Episcopi dioecesiani et propriam vivendi rationem sub ductu eiusdem servet." ${ }^{51}$ In the proposed canon 530, $\$ 2$ in the 1980 schema, "in iure recognoscitur" was substituted for by "in iure agnoscitur." 52 Ultimately, canon $530, \S \S 1-2$ of the 1982 schema, now as canon $604, \S \S 1-2$, was given the following shape: " $\$ 1$. Praeter vitae consecratae instytuta, Ecclesia agnoscit vitam eremiticam seu anachoreticam, qua christifideles, arctiore a mundo secessu, solitudinis silentio, assidua prece et paenitentia, suam in laudem Dei et mundi salutem vitam devovent. \$2. Eremita, uti Deo deditus in vita consecrata, iure agnoscitur si tria evangelica, voto vel alio sacro ligamine firmata, publice profiteatur in manu Episcopi dioecesani et propriam vivendi rationem sub ductu eiusdem servet." 53

consultoribus datis (Patribus Commissionis stricte reservata) (Vatican City: Typis Polyglottis Vaticanis, 1981), 141-42.

${ }^{51}$ Idem, Schema Codicis luris Canonici iuxta animadversiones S.R.E. Cardinalium, Episcoporum Conferentiarum, Dicasteriorum Curiae Romanae, Universitatum Facultatumque ecclesiasticarum necnon Superiorum Institutorum vitae consecratae recognitum (Patribus Commissionis reservatum). Vatican City: Libreria Editrice Vaticana, 128): "§1. In addition to institutes of consecrated life, the Church recognizes eremitic or anchoritic life in which the Christian faithful sacrifice their life to the praise of God and the salvation of the world through a stricter withdrawal from the world, the silence of solitude, and fervent prayer and penance. $\$ 2$. A hermit is recognized by law as one dedicated to God in consecrated life if he or she publicly professes in the hands of the diocesan bishop the three evangelical counsels, confirmed by vow or other sacred bond, and observes a proper program of living under his direction" [retranslated from the Polish version found in ŚMIAROWSKI, Pustelniczy kan. 603, 27-28).

${ }^{52}$ Pontifical Commission for the Revision of the Code of Canon Law, Codex Iuris Canonici. Schema Novissimum iuxta placita Patrum Commissionis emendatum atque Summo Pontifici praesentatum (Vatican City: Typis Polyglottis Vaticanis, 1982), 112.

53 " $\$ 1$. In addition to institutes of consecrated life, the Church recognizes the eremitic or anchoritic life by which the Christian faithful devote their life to the praise of God and the salvation of the world through a stricter withdrawal from the world, the silence of solitude, and assiduous prayer and penance. $\S 2$. A hermit is recognized by law as one dedicated to God in consecrated life if he or she publicly professes in the hands of the diocesan bishop the three evangelical counsels, confirmed by vow or other sacred bond, and observes a proper program of living under his direction" [as it appears on the Vatican website (the CLSA version)—Translator's note]. 


\section{THE CODE OF CANON LAW}

Ultimately, the tenor of canon $603 \mathrm{CIC} / 83^{54}$ is included in Part III, Section I, Title I "Normae communes [...]." This section contains fundamental and doctrinal norms that are relevant to all types of consecrated life. ${ }^{55}$

B.W. Zubert, in his commentary on canon $603 \mathrm{CIC} / 83$, includes eremitic life as one of the new forms of consecrated life. In his opinion, the eremitic life is a lifestyle "in which the faithful sacrifice their life for the glory of God and the salvation of the world through a stricter withdrawal from the world, the silence of solitude, fervent prayer and penance." The theological and canonical elements that determine the distinctiveness of this form of the consecrated life are enumerated in canon $603, \S 1 \mathrm{CIC} / 83$. The norm of the canon in focus does not define what "withdrawing from the world" actually means, but it seems that in the current socio-cultural conditions it does not necessarily have to be a removal from the world in the form known in previous centuries. It seems that nowadays it can take a different form, but it must be a real departure into solitude. ${ }^{56}$ Moving away from the world should be accompanied by silence in seclusion, the practice of fervent prayer and penance, so that the hermit can give his life for the glory of God and the salvation of the world. ${ }^{57}$ The legislator of the Latin Church does not provide for any community forms for this kind of consecrated life. ${ }^{58}$ Although at this point we should mention the phenomenon of anchorites, who indeed live alone but sometimes may settle next to an experienced hermit to become his disciples. Usually there are several of them, but definitely less often a dozen or so. The bonds between anchorites are quite loose and are subject to change depending on the current situation. Such monastic clusters, as a kind

\footnotetext{
${ }^{54}$ See T. RinCón-PÉREZ, "Com. ad can. 603," in Comentario exegético al Código de Derecho Canónico, $3^{\text {rd }}$ ed., ed. Á. Marzoa, J. Miras, and R. Rodríguez-Ocaña (Pamplona: Eunsa, 2002), 2/2: 1497-99.

${ }^{55}$ B.W. ZUBERT, Komentarz do kodeksu prawa kanonicznego z 1983 r., vol. 2/3, Księga II. Lud Boży. Część III. Instytuty życia konsekrowanego i stowarzyszenia życia apostolskiego (Lublin: Redakcja Wydawnictw KUL, 1990), 17.

${ }^{56}$ Ibid., 41.

${ }^{57}$ A. ChrapkowsKi and J. KRZYwDA, "Normy wspólne wszystkim instytutom życia konsekrowanego," in Księga II. Lud Boży. Część 3. Instytuty życia konsekrowanego i stowarzyszenia zycia apostolskiego, ed, J. Krukowski, vol. 2/2 of Komentarz do Kodeksu Prawa Kanonicznego (Poznań: Pallottinum, 2006), 36.

${ }^{58}$ Zubert, Komentarz, 41; compare PAUl VI, Epistula ad Andream Poisson, Ordinis Cartusiensis Ministrum Generalem, ob universae religiosae communitatis coetum habendum. Optimam partem, April 28, 1971, AAS 63 (1971), 447-50.
} 
of personal structure of a hermit colony, are usually referred to in the literature as semi-anchoretic centres ${ }^{59}$ or called lavra in the tradition of the Eastern Church. ${ }^{60}$

According to canon $603, \S 2 \mathrm{CIC} / 83$, a hermit is a person dedicated to God, who "[...] publicly professes in the hands of the diocesan bishop the three evangelical counsels, confirmed by vow or other sacred bond, and observes a proper program of living under his direction."

The profession of the evangelical counsels in the hands of the diocesan bishop $^{61}$ and maintenance of formal dependence on him are theologicalcanonical elements the maintenance of which determines whether or not a faithful person can be regarded as a hermit per se. ${ }^{62}$

The hermit's obligations concern the evangelical counsels as in the case of members of institutes of consecrated life (see canon $674 \mathrm{CIC} / 83$ ). In every case, the diocesan bishop is his superior, which should be defined in a statute issued by the diocesan bishop. ${ }^{63}$ Eremitism has a diocesan character as it is subjected to a diocesan bishop. The term "hermit" is not to be understood as those professed who, according to the norms of law, without losing contact with their own institute, remain obedient to their proper superiors and lead a life of seclusion ad tempus. ${ }^{64}$

The above-mentioned constitutive elements determine the distinctness of this form of consecrated life in the Church. The ecclesiastical legislator speaks in a very general way of "moving away from the world." The eremitic life is governed by the Congregation for the Consecrated Life and the Societies of Apostolic Life. ${ }^{65}$

The promulgation of canon $603, \S \S 1-2 \mathrm{CIC} / 83$ put an end to the difficulties faced by those professed who wished to take up eremitic life. ${ }^{66}$

${ }^{59}$ P. SzCZUR, Początki życia pustelniczego w Kościele, referat wygłoszony na spotkaniu Podkomisji KEP ds. Indywidualnych Form Życia Konsekrowanego, Centrum Promocji IFŻK oraz diecezjalnych referentów ds. IFŻK, March 12, 2016, pp. 3-4, accessed April 8, 2018, http://www.ifzk. episkopat.pl/dokumenty/pustelnicy_2016.pdf.

${ }^{60}$ See J. NAumowicz, "Eawra," in Encyklopedia Katolicka, ed. E. Ziemann (Lublin: Towarzystwo Naukowe KUL, 2006), vol. 11, col. 426.

${ }^{61}$ D.J. ANDRÉs, Il diritto dei religiosi. Commento esegetico al Codice, 2nd ed. (Rome: Ediurcla, 1999), 52.

${ }^{62}$ ZUBERT, Komentarz, 41.

${ }^{63}$ Ibid., 41-42.

${ }^{64}$ Ibid., 42.

65 "Congregationi etiam subiciuntur vita eremitica, ordo virginum harumque consociationes ceteræque formæ vitæ consecratæ" (JoHn PAUL II, Apostolic Constitution Pastor Bonus, June 28, 1988, AAS, 888; English translation available on the Vatican website).

${ }^{66}$ ANDRÉs, Il diritto, 52. 
Pope John Paul II ( $†$ 2005), in his apostolic letter Orientale Lumen of May 2, 1995, ${ }^{67}$ wrote that, as in ancient times, anchoretism continues to show the beauty of its ideal to the modern reader. ${ }^{68}$ The ancient ideal of the anchoretic life, just as it once kindled the hearts and minds of men and women entering the narrow path of eremitic life, it still does nowadays. ${ }^{69}$

\section{CONCLUSION}

As opposed to the 1917 Code of Canon Law, mindful of the circumstances of the present day, the CIC/83 legislator introduced the institution of the eremitic life, also known as anchoretic life, as an individual form of con-

${ }^{67}$ John PAUL, Apostolic Letter Orientale Lumen, May 2, 1995, AAS 87 (1995), 754; English translation available on the Vatican website. Polish translation in "List apostolski «Orientale Lumen» w setną rocznicę Listu apostolskiego «Orientalium dignitatis» papieża Leona XII," in Życie konsekrowane $w$ dokumentach Kościoła: od "Vaticanum II" do "Ripartire da Cristo", ed. B. Hylla, $2^{\text {nd }}$ ed. (Kraków: Alleluja, 2013), pp. 567-68, no. 9, no. 1500.

${ }^{68}$ The Byzantine discipline of anchorites is still observed, for example, on Mount Athos in Greece. Pope Pius XII described the hermit as "religiosus qui, ad normam statutorum vitam anachoreticam ducit, firma dependentia a suae Religionis Superioribus" (PIUS PP. XII, Apostolic letter motu proprio Postquam Apostolicis Litteris, February 9, 1952, AAS 44 (1952), 147, c. 313, §4). The legislator in the Code of Canons of the Eastern Churches divides anchorites into: hermits in the strict sense, members subject to the monastery sui iuris, who, by detaching from the world, are totally committed to contemplating the divine matters (cc. 481-485 CCEO) and other ascetics emulating the eremitic life (c. 570 CCEO; T. RinCón-PÉREZ, "Instytuty życia konsekrowanego i stowarzyszenia życia apostolskiego," in Kodeks Prawa Kanonicznego. Komentarz. Powszechne i partykularne ustawodawstwo Kościoła katolickiego. Podstawowe akty polskiego prawa wyznaniowego, ed. P. Majer, Polish edition based on Spanish edition (Kraków: Wolters Kruwer, 2011), 498.

${ }^{69}$ Eastern monasticism is characterized by unity, but it does not know, as is the case with Latin eremitism, the formation of various forms of apostolic life. The forms of monastic life, from cenobitism as understood by Pachomius ( $† 346)$ or Basil of Caesarea ( $\dagger 379)$ to the most rigorous eremitism, as practiced by Antony the Great $(\dagger 356)$ or Macarius of Egypt $(\dagger 390)$, correspond to stages of a spiritual journey rather than to various choices of the state of life. Moreover, the eastern tradition, not viewing monasticism as a distinct state proper to one category of Christians only, considers it as a point of reference for all baptized persons because of its emblematic importance as a synthesis of Christianity. The spiritual life in the Eastern Church is characterized by a great wealth of forms, among which monasticism is considered to be the most perfect. In contrast to the religious life in the West, eastern monasticism does not have many religious rules as in the case of the Latin West. This is due to the very concept of monastic life, whose sole purpose is to unite with God in a total renunciation of secular life. God, by calling Man to give himself utterly to Him, as in the case of monastic life, gives Man the possibility of attaining the highest degree of what human sensitivity, the great spiritual culture and depth of the heart are able to express. In the eastern perspective, monasticism appears to us as a place of prophetic encounter between Man and God (A. MironOvich, "Specyfika życia monastycznego w Europie Wschodniej," The Eastern European Review 1 (2010): 225). 
secrated life. In this way, the eremitic life was accorded a canonical status in the system of law of the Latin Church. With the consent of diocesan bishops, hermits may form eremitic communities, which, however, do not turn into religious institutes, nor do they constitute forms of community life. The legislator placed the norms of eremitic life in the "normae communes" because the faithful pursuing this type of consecrated life cannot be members of religious or secular institutes.

\section{BIBLIOGRAPHY}

\section{SOURCES OF LAW}

Codex Iuris Canonici auctoritate Ioannis Pauli PP. II promulgatus, January 25, 1983. AAS 75 (1983), pars II, 1-317; Polish translation in Kodeks Prawa Kanonicznego, approved by the Polish Episcopal Conference. Poznań: Pallotinum, 1984.

Codex Iuris Canonici Pii X Pontificis Maximi iussu digestus Benedicti Papae XV auctoritate promulgatus praefatione emi Petrii Gaspari et indice analytico-alphabetico auctus. Vatican City: Typis Polyglottis Vaticanis, 1930.

Corpus iuris canonici. Vol. 2, Decretalium collectiones. Edited by Aeumilius Ludwig Richter and Emil Albert Friedberg. Union, NJ: Lawbook Exchange, 2000.

Grecko-polski Nowy Testament. Wydanie interlinearne z kodami gramatycznymi. Edited by Remigiusz Popowski and Michał Wojciechowski. 7th ed. Warsaw: Oficyna Wydawnicza Vocatio, 1994.

John Paul II. Apostolic Constitution Pastor Bonus, June 28, 1988. AAS 80 (1988), 841-930. English translation available on the Vatican website.

John Paul II. Apostolic Letter Orientale Lumen, May 2, 1995. AAS 87 (1995), 745-74. English translation available on the Vatican website. Polish translation in JOHN PAUL II, List apostolski Orientale Lumen w setną rocznicę Listu apostolskiego Orientalium dignitatis papieża Leona XII, in Życie konsekrowane w dokumentach Kościoła: od Vaticanum II do Ripartire da Cristo, edited by Bernard Hylla, 567-75. 2nd ed. Kraków: Alleluja, 2013.

Kodeks Kościołów Wschodnich promulgowany przez papieża Jana Pawta II. Lublin: Wydział Prawa, Prawa Kanonicznego i Administracji Katolickiego Uniwersytetu Lubelskiego, Wydawnictwo Archidiecezji Lubelskiej Gaudium, 2002.

Paul VI. Epistula ad Andream Poisson, Ordinis Cartusiensis Ministrum Generalem, ob universae religiosae communitatis coetum habendum. Optimam partem, April 28, 1971. AAS 63 (1971), 447-50.

PIUS XII. Litterae Apostolicae motu proprio datae Postquam Apostolicis Litteris, February 9, 1952. AAS 44 (1952), 65-162.

Pontifical Commission for the Revision of the Code of CANON LaW. Codex Iuris Canonici. Schema Novissimum iuxta placita Patrum Commissionis emendatum atque Summo Pontifici praesentatum. Rome: Typis Polyglottis Vaticanis, 1982.

Pontifical Commission for the Revision of the Code of Canon Law. Schema Codicis luris Canonici iuxta animadversiones S.R.E. Cardinalium, Episcoporum Conferentiarum, Dicaste- 
riorum Curiae Romanae, Universitatum Facultatumque ecclesiasticarum necnon Superiorum Institutorum vitae consecratae recognitum (Patribus Commissionis reservatum). Rome: Libreria Editrice Vaticana, 1980.

Pontifical Commission for the Revision of the Code of Canon Law. Acta Commissionis. Opera Consultorum in parandis Canonum Schematibus. De Institutis Perfectionis. Communicationes 6, no. 1 (1974): 72-93.

Pontifical Commission for the Revision of the Code of CAnon Law. Acta Commissionis. De Institutis perfectionis Communicationes 5, no.1 (1973): 47-69.

Pontifical Commission for the Revision of the Code of Canon Law. Acta Commissionis. Schema "De Institutis vitae consecratae" transmittitur. Communicationes 9, no. 1 (1977): 5261.

Pontifical Commission for the Revision of the Code of Canon LaW. Acta Commissionis. Opera Consultorum in recognoscendis schematibus canonum. II: Coetus studiorum de Institutis vitae consecratae per professionem consiliorum evangelicorum. Communicationes 11, no. 2 (1979): 296-346.

Pontifical Commission for the Revision of the Code of Canon law. Ex Actis Pontificiae Commissions Codici Iuris Canonici Recognoscendo. III: Coetus studiorum "De institutis Perfectionis" (Sessio I ${ }^{\mathrm{a}}$ ). Communicationes 16, no. 2 (1984): 196-239.

Pontifical Commission for the Revision of the Code of CANON Law. Relatio. Complectens Synthesim animadversionum ab Em.mis atque Exc.mis Patribus Commissions ad Novissimum Schema Codicis Iuris Canonici Exhibitarum, cum responsionibus a secretaria et consultoribus datis (Patribus Commissionis stricte reservata). Rome: Typis Polyglottis Vaticanis, 1981.

Pontifical Commission for the Revision of the Code of CANON LaW. Schema canonum de Institutis vitae consecratae per professionem consiliorum evangelicorum (reservatum). Rome: Typis Polyglottis Vaticanis, 1977.

VATICAN COUNCIL II. Decree on the adaptation and renewal of religious life Perfectae caritatis, October 28, 1965. AAS 58 (1966): 702-12. English translation available on the Vatican website, http://www.vatican.va/archive/hist_councils/ii_vatican_council/documents/vat-ii_decree _19651028_perfectae-caritatis_en.html. Polish translation in Sobór Watykański II: konstytucje, dekrety, deklaracje: tekst polski. Edited by Julian Groblicki and Eugeniusz Florkowski, 264-75. 3rd ed. Poznań: Pallottinum, 2000.

VATICAN COUNCIL II. Dogmatic constitution on the Church Lumen gentium, November 21, 1964. AAS 57 (1965), 5-75. English translation available on the Vatican website, http://www.vatican. va/archive/hist_councils/ii_vatican_council/documents/vat-ii_const_19641121_lumen-gentium _en.html. Polish translation in Sobór Watykański II: konstytucje, dekrety, deklaracje: tekst polski. Edited by Julian Groblicki and Eugeniusz Florkowski, 105-70. 3rd ed. Poznań: Pallottinum, 2000.

Septuaginta. Id est Vetus Testamentum graece iuxta LXX interpretes edidit Alfred Rahlfs. Editio altera quam recognovit et emendavit Robert Hanhart. Complete Text without Apparatus. Stuttgart: Deutsche Bibelgesellschaft, 2006.

\section{LITERATURE}

MruKównA, Julia. "Eremita s. heremita s. hermitha." In Słownik łaciny średniowiecznej w Polsce. Vol. 3, bk 8, Entafilon-Exactionalis, col. 1168. Wrocław-Warszawa-Kraków-Gdańsk: Polska Akademia Nauk, 1973. 
ANDRÉs, Domingo J. Il diritto dei religiosi. Commento esegetico al Codice. $2^{\text {nd }}$ ed. Rome: Ediurcla, 1999.

BączKowicz, Franciszek, Józef Baron, and Władysław Stawinoga. Prawo kanoniczne. Podręcznik dla duchowieństwa. ${ }^{\text {rd }}$ ed. Vol. 1. Opole: Wydawnictwo Diecezjalne św. Krzyża, 1957.

Benedict of Nursia. "Reguła.” In Reguła Mistrza. Reguła św. Benedykta, 373-503. Tyniec-Kraków: Wydawnictwo Benedyktynów, 2006.

Bianco, Maria G. "Cenobio, cenobita." In Nuovo dizionario patristico e di antichità cristiane. Vol. 1, A-E, edited by Angelo Di Berardino, coll. 984-85. Genova-Milan: Marietti, 1820, 2008.

Bogdan, Franciszek. Prawo zakonów, instytutów świeckich i stowarzyszeń życia apostolskiego. Poznań: Pallottinum, 1988.

BORECKI, Marian. "Eremita." In Stownik polszczyzny XVI wieku, edited by Maria Renata Mayenowa et al. Vol. 6, Dra-Eżby, 559. Wrocław-Warszawa-Kraków-Gdańsk: Zakład Narodowy imienia Ossolińskich, Wydawnictwo Polskiej Akademii Nauk, 1972.

BouIX, Dominique. Tractatus de iure regularium: ubi et de religiosis familiis, quae vota solemnia, vel etiam simplicia perpetua non habent. Vol. 1. Paris: apud Jacobum Lecoffre et Socios, 1857.

ChrapKOwski Arnold, and Józef KRZYwDA. "Normy wspólne wszystkim instytutom życia konsekrowanego." In Księga II. Lud Boży. Część 3. Instytuty życia konsekrowanego i stowarzyszenia życia apostolskiego, edited by Józef Krukowski. Vol. 2, bk 2 of Komentarz do Kodeksu Prawa Kanonicznego, 9-39. Poznań: Pallottinum, 2006.

Clay, Rotha M. The Hermits and Anchorites of England. London: Methuen \& Co, 1914. Accessed April 8, 2018. http://www.historyfish.net/anchorites/clay_anchorites.html.

CONTE A Coronata, Matthaeus. Institutiones iuris canonici ad usum utriusque cleri et scholarum. Vol. 1, Normae generales. De clericis. De religiosis. De laicis. Taurini: Marietti, 1939.

ĆWIKLINSKI, Henryk. “Anachoreci.” In Encyklopedia Katolicka, edited by Feliks Gryglewicz, Romuald Łukaszyk, and Zygmunt Sułowski, vol. 1, coll. 474-75. Lublin: Towarzystwo Naukowe KUL, 1989.

DANILUK, Mirosław, and Jerzy Duchniewski. "Eremici. I. Podstawy ideowe." In Encyklopedia Katolicka, edited by Feliks Gryglewicz, Romuald Łukaszyk, and Zygmunt Sułowski, vol. 4, coll. 1069-1070. Lublin: Towarzystwo Naukowe KUL, 1989.

DANILUK, Mirosław. Encyklopedia instytutów życia konsekrowanego i stowarzyszeń życia apostolskiego. Lublin: Redakcja Wydawnictw KUL, 2000.

Daniluk, Mirosław. "Mnich.” In Encyklopedia Katolicka, edited by Eugeniusz Ziemann, vol. 12, col. 1447. Lublin: Towarzystwo Naukowe KUL, 2008.

DOYERE, Pierre. “Complexité de l'érémitisme.” La vie spirituelle 377 (1952): 243-55.

Doyere, Pierre. "Ermites." In Dictionnaire de Droit Canonique, edited by Raoul Naz, vol. 5, coll. 412-29. Paris: Libraire Letouzey et Ané, 1953.

DOYERE, Pierre. "L'érémitisme dans la vie spirituelle et dans la vie religieuse." La vie spirituelle 377 (1952): 278-88.

DYBSKI, Henryk. "Początki anachretyzmu w Egipcie w świetle nauczania Ojców Kościoła IV i V wieku." Studia Teologiczne 27 (2009): 203-29.

Ferraris, Lucius. Prompta Bibliotheca Canonica, Juridica, Moralis, Theologica, nec non Ascetica, Polemica, Rubricistica, Historica. Vol. 3. Paris: J.P. Migne, 1852. 
Gribomont, Jean. "Anacoreta." In Nuovo dizionario patristico e di antichità cristiane, edited by Angelo Di Berardino, col. 257. Genova-Milan: Marietti, 1820, 2008.

Gribomont, Jean. "Eremita. 1. Filologia.” In Dizionario degli Istituti di Perfezione, edited by Guerrino Pelliccia and Gianco Rocca, col. 1153. Rome: Edizioni Paoline, 1976.

GutiérreZ, Anastasius. "Schema Canonum. De institutis vitae consecratae per professionem consiliorum evangelicorum." Commentarium pro Religiosis et Missionaris 58 (1977): 3-34.

GutiérReZ, Anastasius. "Schema Novi Iuris pro Institutis perfectionis christianae." Commentarium pro Religiosis et Missionaris 58 (1977): 193-209.

Hemmer, Hippolyte. "Anachorètes.” In Dictionnaire de Théologie Catholique, edited by Alfred Vacant et al., vol. 1/1, coll. 1134-41. Paris: Letouzey et Ané, 1909.

HEMPEREK, Piotr and Wojciech GÓRALSKI. Komentarz do kodeksu prawa kanonicznego z 1983 r. Vol. 1/1, Historia źródet i nauki prawa kanonicznego. Lublin: Redakcja Wydawnictw KUL, 1995.

HENRY, Antonin M. “L'érémitisme dans l'histoire.” La vie spirituelle 377 (1952): 306-8.

Hughes-EdwARDS, Mari. "Solitude and Sociability. The World of the Medieval Anchorite." Accessed April 8, 2018. http://www.buildingconservation.com/articles/anchorites/anchorites.htm.

John Cassian. Opera, pars II, JOHANNIS CASSIANI, Co(n)lationes XXIIII. Corpus Scriptorum Ecclesiasticorum Latinorum, edited by Michael Petschenig, vol. 13. Vindobonae: apud C. Geroldi Filivm Bibliopolam Academiae, 1886. Polish translation in Rozmowy z ojcami. Vol. 2, Rozmowy XI-XVII, edited by Szymon Hiżycki. Tyniec: Wydawnictwo Benedyktynów, 2015.

"Itinerarium Egeriae." In Itineraria et alia geographica. Itineraria Hierosolymitana. Itineraria Romana. Geographica. Corpus Christianorum Series Latina 175, edited by Paul Geyer, Otto Cuntz, Ezio Francheschini, Robert Weber, Ludwig Bieler, John Fraipont, Francois Glorie, 35-103. Brepols: Turnhout, 1965.

Jone, Heribertus. Commentarium in Codicem iuris canonici. Vol. 1. Padeborn: Schöningh, 1950.

JONES, Edward A. "Rites of Enclosure. The English «Ordines» for the Enclosing of Anchorites." Traditio 67 (2012): 145-234.

LAMPE, Geoffrey W.H., ed. A Patristic Greek Lexicon. Oxford: Clarendon Press, 1961.

LECLERCQ, Henri. "Erémitisme." In Dictionnaire d'Archéologie Chrétienne et de Liturgie, edited by Fernand Cabrol and Henri Leclercq, vol. 5/1, coll. 384-86. Paris: Letouzey et Ané, 1922.

Liatine, Clément. "Erémitisme.” In Dictionnaire de Spiritualité Ascétique et Mystique Doctrine et Histoire, edited by Marcel Viller, Charles Baumgartner, and Andre Rayez, vol. 4, coll. 936-83. Paris: Beauchesne, 1960.

MACIĄG, Józef. "XX niedziela zwykła “A” (Mt 15,21-2)—Jezus i udręczony świat pogański." Accessed April 8, 2018. http:// sfd.kuria.lublin.pl/index.php/slowo-na-niedziele/lectio-divina/ 3446-uhyjiyuyu.

Miles, Mark G. Canon 603. Diocesan Hermits in the Light of Eremitical Tradition. Rome: Pontificia Universitas Gregoriana, 2003.

Mironowicz, Antoni. "Specyfika życia monastycznego w Europie Wschodniej.” Przegląd Wschodnioeuropejski 1 (2010): 225-41.

Moroni, Gaetano. Dizionario di erudizione storico-ecclesiastica da S. Pietro sino ai nostri giorni. Vol. 22. Venice: Tipografia Emiliana, 1843.

NAumowicz, Józef. "Ławra.” In Encyklopedia Katolicka, edited by Eugeniusz Ziemann, vol. 11, col. 426. Lublin: Towarzystwo Naukowe KUL, 2006. 
OseK, Ewa. “Apendyks 2. Leksykon terminów ascetycznych św. Jana Klimaka.” In John CLimacus. Drabina raju, edited by Ewa Osęk, 368-437. Kęty: Wydawnictwo Marek Derewiecki, 2011.

PILSZAK, Paweł. L'actualité de la vocation a la vie érémitique pour l'Eglise d'aujourd'hui. Ouagadougou: Grand Séminaire Saint Jean-Baptiste de Wayalghin, 2012 [typescript].

ReClus, TheOPHILE. "Plaidoyer pour l'érémitisme." La vie spirituelle 377 (1952): 230-42.

Rincon-Perez, Tomás. “Com. ad can. 603.” In Comentario exegético al Código de Derecho Canónico, $3^{\text {rd }}$ ed., edited by Ángel Marzoa, Jorge Miras, and Rafael Rafael Rodríguez-Ocaña, 2/2:1497-99. Pamplona: Eunsa, 2002.

RINCÓN-PÉREZ, Tomás. "Instytuty życia konsekrowanego i stowarzyszenia życia apostolskiego." In Kodeks Prawa Kanonicznego. Komentarz. Powszechne i partykularne ustawodawstwo Kościoła katolickiego. Podstawowe akty polskiego prawa wyznaniowego, edited by Piotr Majer, 480-576. Polish edition based on Spanish edition. Kraków: Wolters Kruwer, 2011.

Sidonius, Apollinaris. Carmina. In Epistvlae et Carmina. Monumenta Germaniae Historica. Auctores Antiquissimi, $2^{\text {nd }}$ ed., edited by Christian Lütjohann, 2: 173-264. München: Monumenta Germaniae Historica, 1985.

SKorupA, Ambroży. "Wymiar strukturalny życia pustelniczego." Accessed April 8, 2018. http://www.ifzk.episkopat.pl/ dokumenty/sympozjum2016_konf-3.pdf.

Sondermann, Antonina. Praedicatio silentiosa et ecclesia minor. Eremitisches Leben nach dem geltenden Recht der katholischen Kirche. Essen: Ludgerus Verlag, 2014.

Severus, Sulpicius. Dialogus Primus. In Libri qui supersunt. Corpus Scriptorum Ecclesiasticorum Latinorum, edited by Karl Halm, 1: 152-80. Vindobonae: apud C. Geroldi Filium Bibliopolam Academiae, 1866. Polish translation in "Dialogi o życiu św. Marcina." In Pisma $o$ św. Marcinie z Tours. Żywot, listy, dialogi, edited by Marek Starowieyski, 107-87. TyniecKraków: Wydawnictwo Benedyktynów,1995.

SUÁREZ, Francisco. Operis de religione pars secunda: quae est De statu religionis ac tomus tertius in ordine complectens tractatum septimum [...]: in decem libros distributum. Lugduni: sumptibus Iacobi Cardon \& Petri Cauellat, 1624.

SzCZur, Piotr. Początki życia pustelniczego w Kościele, referat wygłoszony na spotkaniu Podkomisji KEP ds. Indywidualnych Form Życia Konsekrowanego, Centrum Promocji IFŻK oraz diecezjalnych referentów ds. IFŻK, March 12, 2016. Accessed April 8, 2018. http://www.ifzk. episkopat.pl/dokumenty/pustelnicy_2016.pdf.

SzEwCZuL, Bożena. Review of "I nuovi eremiti. La 'fuga mundi' nell'Italia di oggi”, Isacco Turina, Milano: Edizioni Medusa 2007, ss. 239." Prawo Kanoniczne 53, nos. $3-4$ (2010): 347-51.

ŚMIARowski, Henryk. Pustelniczy kan. 603: uregulowania kanoniczne diecezjalnego życia pustelniczego w Kościele rzymskokatolickim. Ełk: Fundacja Szlakiem JP2, 2016.

Warren, Ann K. Anchorites and their Patrons in Medieval England. Berkeley-Los AngelesLondon: University of California Press, 1985.

WinANDY, Jacques. "Eremita. In Occidente (statuto canonico)." In Dizionario degli Istituti di Perfezione, edited by Guerrino Pelliccia and Gianco Rocca, vol. 3, coll. 1154-55. Rome: Edizioni Paoline, 1976.

WiPSZYCKA, Ewa. Introduction FOR AthANASIUS. Żywot świętego Antoniego. Św. Antoni Pustelnik. Pisma, 7-27. Warsaw: Instytut Wydawniczy PAX, 1987. 
ZUBERT, Bronisław. Komentarz do kodeksu prawa kanonicznego z 1983 r. Vol. 2/3, Ksiega II. Lud Boży. Cześśc III. Instytuty życia konsekrowanego i stowarzyszenia życia apostolskiego. Lublin: Redakcja Wydawnictw KUL, 1990.

THE FORMATION OF THE CONCEPT OF A HERMIT,

OR AN ANCHORITE, IN THE LIGHT OF THE LATIN CHURCH LAW CODIFICATION AFTER THE SECOND VATICAN COUNCIL

\section{Summary}

The subject of the article is the formation of the concept of a hermit or an anchorite in the light of the codification of the Latin Church law after Vatican II. In canon 603 CIC/83, the legislator uses two terms of a hermit and anchorite, which when used interchangeably have a rich semantics as presented by the author, going back to Christian antiquity. CIC/17 did not normalize the canonical status of eremitic life in the Latin Church. It was not until the period of codification after Vatican II that a canonical norm governing eremitic life was formed. As a result of codification work, eremitic life was recognized by canon $603 \mathrm{CIC} / 83$ as one of the forms of individual consecrated life. In modern times, both in the Byzantine and Latin traditions, eremitic life is flourishing attracting both men and women.

Key words: anachoresis; hesychast; cenobitism; eremitism.

Translated by Tomasz Patkowski

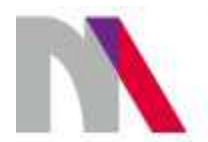

The preparation of the English version of Roczniki Nauk Prawnych (Annals of Iuridical Sciences) and its publication in electronic databases was financed under contract no. 836/PDUN/2018 from the resources of the Minister of Science and Higher Education for the popularization of science. 